\title{
Photosynthetic Rate of the Aquatic Macrophyte Egeria densa Planch. (Hydrocharitaceae) in Two Rivers from the Itanhaém River Basin in São Paulo State, Brazil
}

\author{
Maura Maria Pezzato and Antonio Fernando Monteiro Camargo* \\ Universidade Estadual Paulista; Departamento de Ecologia and CAUNESP; afmc@rc.unesp.br; C. P. 199; \\ 13506-900; Rio Claro - SP - Brazil
}

\begin{abstract}
Egeria densa is a submerged aquatic macrophyte which, in Brazil, causes problems specially for electric energy generation. The purpose of this study was to evaluate the photosynthetic rate ofE. densa in two rivers (Aguapeu and Mambu) with different limnological features, both located in the Itanhaém River Basin. This species is abundant in both rivers without causing damages to their multiple uses. Photosynthetic rates were analysed in February, May, August and November 1998 and limnological variables of the water and sediment were also measured. The highest value of gross photosynthesis (GP) was detected in May (10.06 in Aguapeú and $6.10 \mathrm{mgO} / \mathrm{gDW} / \mathrm{h}$ in Mambu), when under-water photosynthetic active radiation (PAR) was also high $(1,126.7$ and $895.8 \mu \mathrm{mol} / \mathrm{m} / \mathrm{s}$, respectively). GP, total phosphorous, total $\mathrm{CO}_{2}$ and PAR were always higher in Aguapeú River.
\end{abstract}

Key words: Aquatic macrophyte, Egeria densa, photosynthetic rate, Brazil

\section{INTRODUCTION}

Aquatic macrophytes are considered to be one of the main primary producers in shallow water ecosystems; they show a great capacity to adapt to changing environmental conditions and, as a consequence, show a great ecological amplitude (Camargo and Esteves, 1995; Esteves, 1998). These characteristics, together with modifications of the environment caused by man, result in an undesirable growth of several species in some aquatic ecosystems.

The excessive growth of aquatic macrophytes is a result of human activities, which create favourable conditions for their growth (Seshavatharam, 1990). According to Madsen (1998), the nonnative submerged species which cause most problems (affecting navigation, hydroelectric power generation, water supply, recreation and flood control) in the United States are Hydrilla verticillata (L.f.) Royle, Myriophyllum spicatum L. and Egeria densa Planch, known as Brazilian elodea. These three species have biological and physiological characteristics that enable them to exploit the aquatic environment in an opportunistic way, growing and reproducing in sub-optimal conditions, even when in competition with other species (Spencer and Bowes, 1990).

For the management of submerged species, it is important to know about the conditions that favour and/or limit their growth, and one way is to estimate the photosynthetic rate. The photosynthesis and respiration rates of submerged macrophytes are directly related to temperature

*Author for correspondence 
and light (Menendez and Peñuelas, 1993; Menendez and Sanches, 1998), as well as to nutrient availability, including dissolved carbon and oxygen (Sand-Jensen, 1989; Madsen and Sand-Jensen, 1994; Feijoó et al., 1996; Madsen et al., 1998). These variables can affect the photosynthetic characteristics of the plant, both seasonally (e.g. light and temperature) and diurnally (e.g. $\mathrm{O}_{2}$ and $\mathrm{CO}_{2}$ ), and as such they can have combined effects in modifying the photosynthetic characteristics (Sand-Jensen, 1989).

E. densa and Egeria najas Planch. are two submerged macrophyte species that have been growing abundantly in some of the Brazilian reservoirs, and so having adverse effects on the hydroelectric power generation (Thomas et al., 1999). However, studies about limnological features that influence their growth and photosynthetic rates are few, especially, in their native habitats.

The objective of this study was to measure the photosynthetic rates of $E$. densa and to determine the main limnological variables involved in the control of the photosynthesis and respiration of this species.

\section{MATERIAL AND METHODS}

The measurements of photosynthesis, respiration and of the physicochemical characteristics of the water and sediment were taken in quarterly intervals during 1998: February (summer), May (autumn), August (winter) and November (spring). The photosynthetic rate was measured in sites where $E$. densa occurred in both rivers using water from their own environment. Clear $(97 \%$ of transparency) and dark flasks with ca. $2000 \mathrm{ml}$ capacity were filled up with water using a siphon. Apical branches of $E$. densa, with approximately $15 \mathrm{~cm}$ length $(0.35 \mathrm{~g}$ of dry weight) were placed in each flask. The incubations were done in triplicate. For further correction of the photosynthesis and respiration of the macrophyte, the production and respiration of the phytoplankton was measured from one clear and one dark flask that did not contain the plant. The incubations were placed on the surface and at the bottom of the river ( 0.9 to $1.8 \mathrm{~m}$ depending on the river and sampling period), in horizontal position, for a period of $4 \mathrm{~h}$ (approximately 10:00 to 14:00 h). Afterwards the water from the flasks was siphoned to $150 \mathrm{ml}$ flasks for the measurements of dissolved $\mathrm{O}_{2}$
(mg/L) using the Winkler's method (Golterman et al., 1978). The titration was made by an electronic burette (Scohtt Gerate, model T 80/10). Dry weight of the plant material used in the incubations was obtained by drying it at $60^{\circ} \mathrm{C}$ until constant weight.

The gross and net photosynthesis and the respiration were calculated using the following equations described in Vollenweider (1974):

$$
\begin{gathered}
N P=(c-i) v /(t . D W) \\
R=(i-d) v /(t . D W) \\
G P=N P P+R
\end{gathered}
$$

$N P$ being the net photosynthesis $\left(\mathrm{mgO}_{2} / \mathrm{gDW} / \mathrm{h}\right)$, $R:$ respiration $\left(\mathrm{mgO}_{2} / \mathrm{gDW} / \mathrm{h}\right), \quad G P:$ gross photosynthesis $\quad\left(\mathrm{mgO}_{2} / \mathrm{gDW} / \mathrm{h}\right), \quad c: \quad \mathrm{O}_{2}$ concentration in the clear flask and $d$ in the dark flasks $(\mathrm{mg} / \mathrm{L}), i$ : initial $\mathrm{O}_{2}$ concentration in the flasks $(\mathrm{mg} / \mathrm{L}), v$ : flask volume $(\mathrm{L}), t$ : incubation time (h) and $D W$ : plant dry weight (grams).

At the beginning of the incubation, values of $\mathrm{pH}$, electrical conductivity (El. cond.) $(\mu \mathrm{S} / \mathrm{cm})$, temperature $\left({ }^{\circ} \mathrm{C}\right)$ and turbidity (NTU) were taken in triplicates, using the Water Quality Checker, Horiba (model U10). The photosynthetic active radiation (PAR) $\left(\mu \mathrm{mol} / \mathrm{m}^{2} / \mathrm{s}\right)$ was measured with the Light Meter LiCor (model 189) coupled to an underwater Quantum Sensor Licor (model 192) and the coefficient of the vertical attenuation $(\mathrm{k})$ was calculated using the following equation: $k=$ $(\ln . I o-\ln . I) / z$, where $\ln$ is the natural logarithm, $I$ is the PAR at a determined depth $(\mathrm{m}), I o$ is the PAR at the surface and $z$ is the depth (m) (Wetzel, 1975). Water (1 L) for further measurement of the total alkalinity (meq/L), by titration, and total $\mathrm{CO}_{2}$ concentration $(\mathrm{mg} / \mathrm{L})$, according to Mackereth et al. (1978) was sampled, in triplicates, from the site where the incubation had been carried out. Approximately $0.5 \mathrm{~L}$ of the water sample was filtered (Whatman GF/C) in the field laboratory, kept in polyethylene flasks and frozen to $-20{ }^{\circ} \mathrm{C}$. Non filtered samples $(0.5 \mathrm{~L})$ were also frozen in the same manner.

The concentration of ammoniacal nitrogen $(\mathrm{N}$ ammoniacal) $(\mu \mathrm{g} / \mathrm{L})$ (Koroleff, 1976), nitrite (N$\left.\mathrm{NO}_{2}\right)(\mu \mathrm{g} / \mathrm{L})$, nitrate $\left(\mathrm{N}-\mathrm{NO}_{3}\right)(\mu \mathrm{g} / \mathrm{L})$ and total dissolved $\mathrm{N}$ (TDN) (mg/L) (Mackereth et al., 1978) as well as total dissolved $\mathrm{P}$ (TDP) $(\mu \mathrm{g} / \mathrm{L})$ and orthophosphates $\left(\mathrm{P}^{-} \mathrm{PO}_{4}\right)(\mu \mathrm{g} / \mathrm{L})$ (Golterman et al., 1978) were measured from the filtered samples in the Laboratory of Aquatic Ecology 
from the Department of Ecology of UNESP/Rio Claro-SP. The total suspended matter (Susp. matter) $(\mu \mathrm{g} / \mathrm{L})$ was determined according to Clesceri et al. (1989). The non-filtered water samples were used to determine total nitrogen (TN) (mg/L) (Mackereth et al., 1978) and total phosphorus (TP) ( $\left.\mu \mathrm{g} \mathrm{L}^{-1}\right)$ (Golterman et al., 1978). Samples sediment were also collected in triplicates to measure total nitrogen (TN) (\%PS), using the Kjeldahl method (Allen et al., 1974), and total phosphorus (TP) (\%PS) (Esteves, 1980) and organic matter (Org. matter) (\%PS) by incineration at $500{ }^{\circ} \mathrm{C}$.

Apical branches of $E$. densa were also collected in triplicate from the banks of the two rivers, near the site where the incubation was carried out, for further measurement of chlorophyll $a$ and $b$ (\% PS) using the method by Vollenweider (1974). For these measurements, fresh branches of $E$. densa were washed to remove periphyton and debris and kept frozen in the dark to avoid chlorophyll degradation.

The Principal Components Analysis (Ludwig and Reynolds, 1988), based on the abiotic variables measured, was used to ordinate the sites (rivers) and data collection times. For this analysis and for the variance analysis (ANOVA), the statistic software SYSTAT (version 5.03) was used (Wilkinson, 1990). For the analysis of variance the data were transformed, if necessary, and differences were considered significant when $\mathrm{p}<0.05$.

\section{STUDY AREA}

This study was carried out in the Aguapeú and Mambu rivers located in the hydrographic basin of the Itanhaém River. In these rivers, $E$. densa grows in dense stands but does not influence the river's multiple uses. This hydrographic basin has a total area of $900 \mathrm{~km}^{2}$ and it is located on the South coast of São Paulo State, South-eastern Brazil (Camargo et al., 1997).

Fifty percent of the basin is located in a mountain range region with altitudes varying between 500 and $1000 \mathrm{~m}$, covered by dense vegetation of a well preserved area of tropical rain forest in the State Park of the Sea Range (Parque Estadual da Serra do Mar). The remaining $50 \%$ of the area of the basin are located in the coastal plain with an altitude up to $20 \mathrm{~m}$ and a well preserved natural vegetation in some parts and disturbed areas consisting of banana farms. The middle and final sections of the two rivers meander through the coastal plain with a slow current (Camargo et al., 1997).

Aguapeú River has black water while Mambu River has clear water, both rivers have low current velocity $(0.4 \mathrm{~cm} / \mathrm{s}$ in Aguapeú River and $0.3 \mathrm{~cm} / \mathrm{s}$ in Mambu River). In the coastal plain, the Aguapeú River is colonised by several macrophyte species, including floating species (e.g. Pistia stratiotes L., Salvinia molesta D.S. Mitchell, Eichhornia crassipes (Mart.) Solms), emergent species (e.g. Eichhornia azurea (Swartz) Kunth), floating leaves species (e.g. Nymphaea rudgeana C. F. Mey) and submerged species (Cabomba furcata Schult and Schult. f., Egeria densa Planch.), while the Mambu River is colonised only by submerged species (Cabomba furcata, Egeria densa).

According to Lamparelli and Moura (1998), the climate of the region presents little variation due to its latitude and the proximity to the Atlantic Ocean. Rain is abundant (annual mean of 2183 $\mathrm{mm}$ ) and well distributed throughout the year, with more rainfall in March (279.9 $\mathrm{mm})$ and less in August $(84.7 \mathrm{~mm})$. The atmospheric temperature in the region is high, with a minimum mean of $19.0{ }^{\circ} \mathrm{C}$ (July) and a maximum mean of $26.2{ }^{\circ} \mathrm{C}$ (February). There is little variation of the annual photoperiod with slightly longer days in summer $(13 \mathrm{~h})$ than in winter $(11 \mathrm{~h})$. Solar radiation varies mainly according to the alternation of sunny and rainy days during all seasons of the year.

\section{RESULTS}

The values of the physical and chemical variables of the water and the sediment of the Aguapeú River are presented in Table 1. The water temperature variation was small during the period of analysis, with a maximum of $23.7^{\circ} \mathrm{C}$ in February and a minimum of $20.2{ }^{\circ} \mathrm{C}$ in August and November. The highest amount of dissolved $\mathrm{CO}_{2}$ was found in the water of the Aguapeú River, with a maximum of $5.45 \mathrm{mg} / \mathrm{L}$ in November and a minimum of $3.08 \mathrm{mg} / \mathrm{L}$ in August. 
Table 1 - Values (mean and standard deviations) of physical and chemical variables of the water and sediment, in the Aguapeú River. Values followed by different letters indicate significant differences ( $\mathrm{p}<0.05)$, among months. (depth: $13 / 02=1.80 \mathrm{~m} ; 01 / 05=1.60 \mathrm{~m} ; 12 / 08=1.00 \mathrm{~m} ; 04 / 11=0.90 \mathrm{~m} ;$ - not measured; $\mathrm{n}=3$ ).

\begin{tabular}{|c|c|c|c|c|}
\hline Variables & $12 / 02 / 98$ & $02 / 05 / 98$ & $13 / 08 / 98$ & $05 / 11 / 98$ \\
\hline Temperature & $23.7 \pm 0.05 \mathrm{a}$ & $21.8 \pm 0.23 b$ & $20.2+0.00 \mathrm{c}$ & $20.2 \pm 0.06 \mathrm{c}$ \\
\hline Turbidity & $9 \pm 0.57 \mathrm{a}$ & $8 \pm 2.51 \mathrm{a}$ & $10 \pm 3.46 \mathrm{a}$ & $4 \pm 1.00 \mathrm{~b}$ \\
\hline El. cond. & $27 \pm 0.00 a$ & $32 \pm 0.00 b$ & $40 \pm 0.00 c$ & $27 \pm 0.00 \mathrm{a}$ \\
\hline $\mathrm{pH}$ & $5.32 \pm 0.11 \mathrm{a}$ & $5.42 \pm 0.02 \mathrm{a}$ & $5.97 \pm 0.05 b$ & $5.41 \pm 0.51 \mathrm{a}$ \\
\hline Dissolved $\mathrm{O}_{2}$ & $2.89 \pm 0.04 \mathrm{a}$ & $2.24 \pm 0.63 \mathrm{a}$ & $6.13 \pm 0.39 b$ & $3.77 \pm 0.03 \mathrm{c}$ \\
\hline Alkalinity & $0.67 \pm 0.00 \mathrm{a}$ & $0.96 \pm 0.06 b$ & $1.91 \pm 0.05 \mathrm{c}$ & $1.14 \pm 0.32 \mathrm{~b}$ \\
\hline Total $\mathrm{CO}_{2}$ & $3.67 \pm 0.80 \mathrm{a}$ & $4.31 \pm 0.39 \mathrm{a}$ & $3.08 \pm 0.18 \mathrm{a}$ & $5.45 \pm 2.07 \mathrm{a}$ \\
\hline $\operatorname{PAR}(0 \mathrm{~cm})$ & $65.26 \pm 18.80 \mathrm{a}$ & $1,126.67 \pm 37.76 b$ & $206.26 \pm 120.04 \mathrm{a}$ & $366.52 \pm 246.59 a$ \\
\hline PAR (bottom) & - & $61.54 \pm 10.17 \mathrm{a}$ & $36.79 \pm 44.52 \mathrm{a}$ & $25.78 \pm 14.52 \mathrm{a}$ \\
\hline $\mathrm{k}(0-0.20)$ & $2.98 \pm 0.58 \mathrm{a}$ & $2.7 \overline{6} \pm 0.13 \mathrm{a}$ & $2.89 \pm 0.62 \mathrm{a}$ & $4.72 \pm 3.05 \mathrm{a}$ \\
\hline $\mathrm{TN}$ & $0.37 \pm 0.04 \mathrm{a}$ & $0.21 \pm 0.70 \mathrm{~b}$ & $0.36 \pm 0.01 \mathrm{a}$ & $0.33 \pm 0.09 \mathrm{a}$ \\
\hline TDN & $0.26 \pm 0.04 \mathrm{a}$ & $0.28 \pm 0.70 \mathrm{a}$ & $0.29 \pm 0.04 \mathrm{a}$ & $0.17 \pm 0.29 \mathrm{a}$ \\
\hline $\mathrm{N}-\mathrm{NO}_{2}$ & $7.7 \pm 1.29 \mathrm{a}$ & $9.9 \pm 5.02 \mathrm{a}$ & $9.7 \pm 1.84 \mathrm{a}$ & $6.5 \pm 0.29 a$ \\
\hline $\mathrm{N}-\mathrm{NO}_{3}$ & $13.2 \pm 14.52 \mathrm{a}$ & $48.6 \pm 33.75 \mathrm{a}$ & $33.6 \pm 20.81 \mathrm{a}$ & $196.8 \pm 11.94 b$ \\
\hline N-ammoniacal & $3.2 \pm 0.44 \mathrm{a}$ & $<3.0 \pm 0.00 \mathrm{a}$ & $3.8 \pm 1.49 \mathrm{~b}$ & $5.0 \pm 1.17 \mathrm{~b}$ \\
\hline TP & $85.3 \pm 13.87 \mathrm{a}$ & $38.8 \pm 6.98 \mathrm{~b}$ & $47.7 \pm 6.70 b$ & $39.9 \pm 12.60 b$ \\
\hline TDP & $59.4 \pm 12.83 \mathrm{a}$ & $26.3 \pm 2.45 b$ & $30.2 \pm 2.70 b$ & $27.7 \pm 4.41 b$ \\
\hline $\mathrm{P}-\mathrm{PO}_{4}$ & $45.8 \pm 15.67 \mathrm{a}$ & $17.8 \pm 3.38 b$ & $17.5 \pm 8.98 b$ & $14.9 \pm 2.97 b$ \\
\hline Susp. matter & $5.4 \pm 1.95 \mathrm{a}$ & $7.1 \pm 4.11 \mathrm{a}$ & $3.2 \pm 0.75 \mathrm{a}$ & $4.6 \pm 2.18 \mathrm{a}$ \\
\hline TP sediment & $0.045 \pm 0.02 \mathrm{a}$ & $0.058 \pm 0.01 \mathrm{a}$ & $0.008 \pm 0.00 \mathrm{~b}$ & $0.005 \pm 0.01 b$ \\
\hline TN sediment & $0.16 \pm 0.01 \mathrm{a}$ & $0.03 \pm 0.00 \mathrm{~b}$ & $0.36 \pm 0.09 \mathrm{c}$ & $0.20 \pm 0.07 \mathrm{a}$ \\
\hline Org. matter & $0.16 \pm 0.00 \mathrm{a}$ & $0.17 \pm 0.01 \mathrm{a}$ & $0.17 \pm 0.01 \mathrm{a}$ & $0.26 \pm 0.02 b$ \\
\hline
\end{tabular}

The photosynthetic active radiation (PAR) measured on the surface was higher in May $\left(1,126.67 \mu \mathrm{mol} / \mathrm{m}^{2} / \mathrm{s}\right)$, being statistically different from the measurements obtained during the other months $(\mathrm{F}=33.53, \mathrm{p}=0.00007)$. The PAR value measured at the bottom $(1.60 \mathrm{~m})$ in May was 61.54 $\mu \mathrm{mol} / \mathrm{m}^{2} / \mathrm{s}$, being eighteen times lower than the value measured at the surface.

The values of $\mathrm{k}$ were not statistically different, varying between 2.76 and $4.72(\mathrm{~F}=4.24, \mathrm{p}=$ $0.052)$. The values of the physical and chemical variables of the water and the sediment of the Mambu River are presented in Table 2. The water temperature variation was small during the period of analysis, with a maximum of $21.2{ }^{\circ} \mathrm{C}$ in February and a minimum of $18.2^{\circ} \mathrm{C}$ in November. The maximum concentration of $\mathrm{CO}_{2}$ in the water was found in February $(3.78 \mathrm{mg} / \mathrm{L})$ and the minimum in August $(0.54 \mathrm{mg} / \mathrm{L})$. The PAR measured on the surface was higher in May (895.77 $\mu \mathrm{mol} / \mathrm{m}^{2} / \mathrm{s}$ ) being statistically different from the measurements obtained for the other months $(\mathrm{F}=28.18, \mathrm{p}=0.00013)$. The PAR measured at the bottom $(1.30 \mathrm{~m})$ in May $(172.41$ $\mu \mathrm{mol} / \mathrm{m}^{2} / \mathrm{s}$ ) was five times lower than at the surface. The values of $\mathrm{k}$ obtained at the different months during the analysis were not statistically different, but were lower than the ones obtained for the Aguapeú River, varying between 1.51 and $2.27(\mathrm{~F}=0.89, \mathrm{p}=0.458)$. The values GP, NP and $\mathrm{R}$ of $E$. densa are shown in Table 3. In the Aguapeú River, the highest GP was measured in May at both the surface $\left(10.06 \mathrm{mgO}_{2} / \mathrm{gDW} / \mathrm{h}\right)$ and the bottom $\left(6.10 \mathrm{mgO}_{2} / \mathrm{gDW} / \mathrm{h}\right)$ of the river. The GP was two times higher at the surface than at the bottom during all months except February, when the values were nine times higher.

In the Mambu River, the higher GP was also measured in May both on the surface (6.10 $\left.\mathrm{mgO}_{2} / \mathrm{gDW} / \mathrm{h}\right)$ and on the bottom (5.60 $\left.\mathrm{mgO}_{2} / \mathrm{gDW} / \mathrm{h}\right)$. On the surface, there were significant differences between the values obtained for May and the other months. The differences in the GP at the surface and bottom in the Mambu River were lower than in the Aguapeú River. 
Table 2 - Values (mean and standard deviations) of physical and chemical variables of the water and sediment, in the Mambu River. Values followed by different letters indicate significant differences, $(\mathrm{p}<0.05)$, among months. (depth: $13 / 02=1.70 \mathrm{~m} ; 01 / 05=1.30 \mathrm{~m} ; 12 / 08=1.00 \mathrm{~m} ; 04 / 11=1.00 \mathrm{~m} ;$ - not measured; $\mathrm{n}=3$ ).

\begin{tabular}{lrrrrr}
\hline Variables & $\mathbf{1 3 / 0 2 / 9 8}$ & $\mathbf{0 1 / 0 5 / 9 8}$ & $\mathbf{1 2 / 0 8 / 9 8}$ & $\mathbf{0 4 / 1 1 / 9 8}$ \\
\hline Temperature & $21.2 \pm 0.11 \mathrm{a}$ & $19.2 \pm 0.34 \mathrm{~b}$ & $19.1 \pm 0.23 \mathrm{~b}$ & $18.2 \pm 0.05 \mathrm{c}$ \\
Turbidity & $3 \pm 1.15 \mathrm{a}$ & $7 \pm 1.52 \mathrm{~b}$ & $4 \pm 0.57 \mathrm{c}$ & $8 \pm 0.57 \mathrm{~b}$ \\
El. cond. & $2 \pm 0.00 \mathrm{a}$ & $9 \pm 0.00 \mathrm{~b}$ & $19 \pm 0.00 \mathrm{c}$ & $6 \pm 0.00 \mathrm{~d}$ \\
pH & $5.34 \pm 0.11 \mathrm{a}$ & $5.94 \pm 0.12 \mathrm{a}$ & $7.82 \pm 0.40 \mathrm{~b}$ & $6.59 \pm 0.51 \mathrm{c}$ \\
Dissolved $\mathrm{O}_{2}$ & $7.73 \pm 0.18 \mathrm{a}$ & $7.31 \pm 0.77 \mathrm{a}$ & $7.43 \pm 0.03 \mathrm{a}$ & $9.18 \pm 0.51 \mathrm{~b}$ \\
Alkalinity & $0.63 \pm 0.06 \mathrm{a}$ & $1.15 \pm 0.44 \mathrm{~b}$ & $1.15 \pm 0.02 \mathrm{~b}$ & $0.63 \pm 0.01 \mathrm{a}$ \\
Total CO $\mathrm{CO}_{2}$ & $3.48 \pm 0.98 \mathrm{a}$ & $1.94 \pm 0.48 \mathrm{~b}$ & $0.54 \pm 0.01 \mathrm{c}$ & $0.56 \pm 0.27 \mathrm{c}$ \\
PAR $(0 \mathrm{~cm})$ & $154.42 \pm 60.71 \mathrm{a}$ & $895.77 \pm 197.71 \mathrm{~b}$ & $128.50 \pm 27.37 \mathrm{a}$ & $410.53 \pm 101.89 \mathrm{c}$ \\
PAR (bottom) & & - & $172.41 \pm 223.48 \mathrm{a}$ & $30.18 \pm 2.50 \mathrm{~b}$ & $85.00 \pm 52.82 \mathrm{a}$ \\
$\mathrm{k}(0-0.20)$ & $2.27 \pm 0.76 \mathrm{a}$ & $1.51 \pm 0.91 \mathrm{a}$ & $1.75 \pm 0.99 \mathrm{a}$ & $2.05 \pm 0.37 \mathrm{a}$ \\
TN & $0.37 \pm 0.04 \mathrm{a}$ & $0.19 \pm 0.04 \mathrm{~b}$ & $0.35 \pm 0.06 \mathrm{a}$ & $0.30 \pm 0.03 \mathrm{a}$ \\
TDN & $0.27 \pm 0.04 \mathrm{a}$ & $0.28 \pm 0.07 \mathrm{a}$ & $0.26 \pm 0.04 \mathrm{a}$ & $0.28 \pm 0.04 \mathrm{a}$ \\
$\mathrm{N}-\mathrm{NO}_{2}$ & $17.1 \pm 22.14 \mathrm{a}$ & $7.4 \pm 0.98 \mathrm{a}$ & $6.8 \pm 0.50 \mathrm{a}$ & $4.9 \pm 2.55 \mathrm{a}$ \\
$\mathrm{N}-\mathrm{NO}_{3}$ & $26.9 \pm 22.13 \mathrm{a}$ & $185.8 \pm 81.21 \mathrm{~b}$ & $78.6 \pm 34.97 \mathrm{a}$ & $224.5 \pm 63.83 \mathrm{~b}$ \\
$\mathrm{~N}-\mathrm{ammoniacal}$ & $3.2 \pm 1.11 \mathrm{a}$ & $<3.0 \pm 0.00 \mathrm{~b}$ & $4.5 \pm 0.47 \mathrm{c}$ & $<3.0 \pm 0.00 \mathrm{a}$ \\
TP & $21.3 \pm 4.98 \mathrm{a}$ & $22.2 \pm 7.196 \mathrm{a}$ & $38.9 \pm 19.76 \mathrm{a}$ & $29.0 \pm 4.73 \mathrm{a}$ \\
TDP & $7.5 \pm 4.02 \mathrm{a}$ & $15.4 \pm 4.66 \mathrm{~b}$ & $19.0 \pm 8.79 \mathrm{~b}$ & $<3.0 \pm 0.00 \mathrm{c}$ \\
$\mathrm{P}-\mathrm{PO}_{4}$ & $<3.0 \pm 0.00 \mathrm{a}$ & $<3.0 \pm 0.00 \mathrm{a}$ & $4.0 \pm 2.44 \mathrm{~b}$ & $<3.0 \pm 0.00 \mathrm{a}$ \\
Susp. Matter. & $7.4 \pm 0.36 \mathrm{a}$ & $3.2 \pm 0.34 \mathrm{~b}$ & $1.3 \pm 0.38 \mathrm{c}$ & $4.3 \pm 0.78 \mathrm{~d}$ \\
TP sediment & $0.015 \pm 0.01 \mathrm{a}$ & $0.011 \pm 0.01 \mathrm{a}$ & $0.001 \pm 0.00 \mathrm{a}$ & $0.012 \pm 0.00 \mathrm{a}$ \\
TN sediment & $0.42 \pm 0.07 \mathrm{a}$ & $0.42 \pm 0.04 \mathrm{a}$ & $0.11 \pm 0.02 \mathrm{~b}$ & $0.07 \pm 0.03 \mathrm{~b}$ \\
Org. matter & $0.19+0.00 \mathrm{a}$ & $0.22+0.00 \mathrm{~b}$ & $0.20+0.01 \mathrm{~b}$ & $0.28+0.01 \mathrm{c}$ \\
\hline
\end{tabular}

Table 3 - Values (mean and standard deviations) for four months of the year 1998 of the net photosynthesis (NP), respiration (R) and gross photosynthesis $(\mathrm{GP})\left(\mathrm{mg} \mathrm{O}_{2} \mathrm{~g}^{-1} \mathrm{DW} \quad \mathrm{h}^{-1}\right)$ on the surface and at the bottom of the Aguapeú River and Mambu River, (mean values and standard deviations followed by different letters indicate significant differences, $(\mathrm{p}<0.05)$, among months, $\mathrm{n}=3)$.

\begin{tabular}{|c|c|c|c|c|}
\hline Aguapeú & $12 / 02 / 98$ & $02 / 05 / 98$ & 13/08/98 & $05 / 11 / 98$ \\
\hline \multicolumn{5}{|l|}{ Surface } \\
\hline NPP & $7.89 \pm 1.77 \mathrm{a}$ & $9.23 \pm 1.64 \mathrm{a}$ & $5.85 \pm 1.27 \mathrm{a}$ & $7.45 \pm 1.78 \mathrm{a}$ \\
\hline $\mathrm{R}$ & $0.44 \pm 0.09 \mathrm{a}$ & $0.82 \pm 1.21 \mathrm{a}$ & $0.72 \pm 0.73 \mathrm{a}$ & $0.88 \pm 0.76 \mathrm{a}$ \\
\hline GPP & $8.34 \pm 1.85 \mathrm{a}$ & $10.06 \pm 0.52 \mathrm{a}$ & $6.57 \pm 1.65 \mathrm{a}$ & $8.33 \pm 1.38 \mathrm{a}$ \\
\hline \multicolumn{5}{|l|}{ Bottom } \\
\hline NPP & $0.46 \pm 0.60 b$ & $4.13 \pm 1.24 \mathrm{a}$ & $2.73 \pm 0.50 \mathrm{a}$ & $3.06 \pm 1.18 \mathrm{a}$ \\
\hline $\mathrm{R}$ & $0.42 \pm 0.42 \mathrm{a}$ & $0.91 \pm 1.12 \mathrm{a}$ & $1.73 \pm 0.55 \mathrm{a}$ & $0.61 \pm 0.09 a$ \\
\hline GPP & $0.89 \pm 0.84 b$ & $5.04 \pm 1.45 \mathrm{a}$ & $4.46 \pm 1.05 \mathrm{a}$ & $3.67 \pm 1.09 \mathrm{a}$ \\
\hline$M a m b u$ & $13 / 02 / 98$ & $01 / 05 / 98$ & $12 / 08 / 98$ & $04 / 11 / 98$ \\
\hline \multicolumn{5}{|l|}{ Surface } \\
\hline NPP & $2.76 \pm 0.45 b$ & $5.40 \pm 1.50 \mathrm{a}$ & $3.32 \pm 0.32 b$ & $3.34 \pm 0.65 b$ \\
\hline $\boldsymbol{R}$ & $0.60 \pm 0.39 b$ & $0.70 \pm 0.61 b$ & $1.44 \pm 0.28 \mathrm{a}$ & $1.44 \pm 0.28 \mathrm{a}$ \\
\hline GPP & $3.37 \pm 0.85 b$ & $6.10 \pm 2.05 \mathrm{a}$ & $3.45 \pm 0.40 \mathrm{~b}$ & $4.79 \pm 0.92 b$ \\
\hline \multicolumn{5}{|l|}{ Bottom } \\
\hline NPP & $2.12 \pm 0.45 b$ & $3.60 \pm 0.17 \mathrm{a}$ & $1.18 \pm 0.13 \mathrm{c}$ & $3.27 \pm 0.28 \mathrm{a}$ \\
\hline $\mathrm{R}$ & $0.93 \pm 0.88 \mathrm{a}$ & $2.03 \pm 0.50 \mathrm{a}$ & $1.74 \pm 0.27 \mathrm{a}$ & $1.31 \pm 0.15 \mathrm{a}$ \\
\hline GPP & $3.06 \pm 0.77 \mathrm{c}$ & $5.60 \pm 0.67 \mathrm{a}$ & $2.92 \pm 0.19 \mathrm{c}$ & $4.58 \pm 0.11 b$ \\
\hline
\end{tabular}


Table 4 presents the correlation between variables with principal components, Factor I and II, which together explained $76 \%$ of the total variation. Temperature, total $\mathrm{CO}_{2}$ and phosphorous concentration in the water and sediment were positively correlated to Factor I, while dissolved $\mathrm{O}_{2}$ was negatively correlated to the same factor. The variables correlated to Factor II were PAR in surface (negative correlation) and TN in the water (positive correlation).

Fig. 1 shows the ordination by principal components (I and II) of the locals (rivers) and date of sampling collection. On the left side of Factor I, are the data for Mambu River (13/02/98, 01/05/98, 12/08/98 and 04/11/98) and 13/08/98 in the Aguapeú River showing lower temperatures, total $\mathrm{CO}_{2}$ and phosphorous concentrations in the water and sediment and higher levels of dissolved
$\mathrm{O}_{2}$ in the water. On the right side of Factor I are the data taken from the Aguapeú River (12/02/98, 02/05/98 and 05/11/98) showing to have opposite characteristics compared to the ones from the left side. In relation to Factor II, it was observed that in May, in both rivers, the values obtained for PAR in the surface were higher than the values obtained in the other months, whereas TN concentration in the water were lower.

The concentrations of chlorophyll $a$ and $b$ in $E$. densa in the Aguapeú and Mambu rivers are presented in Table 5. In November chlorophyll $a$ and $b$ concentrations in the Aguapeú River were significantly $(\mathrm{p}<0.05)$ lower than the measurements taken during the other months. However, in Mambu River there were no significant differences in the chlorophyll concentrations during the time of analysis.

Table 4 - Correlation of the variables with principal component (Factors I and II) in the Aguapeú and Mambu rivers $(*$ indicates high correlation between variables and factors, Expl. Var.= Explained Variance and Prp. Totl= Proportion of Total Variance Explained).

\begin{tabular}{lrr}
\hline \multicolumn{1}{c}{ Variable } & Factor I & Factor II \\
\hline Temperature & $0.909^{*}$ & 0.234 \\
Dissolved $\mathrm{O}_{2}$ & $-0.954^{*}$ & 0.125 \\
Total $\mathrm{CO}_{2}$ & $0.733^{*}$ & -0.026 \\
PAR(surface) & 0.134 & $-0.988^{*}$ \\
TN & 0.021 & $0.973^{*}$ \\
TP & $0.718^{*}$ & 0.498 \\
TN sediment) & -0.312 & 0.161 \\
TP (sediment) & $0.888^{*}$ & -0.304 \\
Expl. Var. & & \\
Prp. Totl & 3.694 & 2.360 \\
\hline
\end{tabular}

Table 5 - Concentrations (mean and standard deviations) of chlorophyll $a$ and $b$ in $E$. densa in the Aguapeú and Mambu rivers. (Mean values and standard deviations followed by different letters indicate significant differences $(\mathrm{p}<0.05)$ between the months; $\mathrm{n}=3)$.

\begin{tabular}{ccccc}
\hline Aguapeú & $\mathbf{1 2 / 0 2 / 9 8}$ & $\mathbf{0 2 / 0 5 / 9 8}$ & $\mathbf{1 3 / 0 8 / 9 8}$ & $\mathbf{0 5 / 1 1 / 9 8}$ \\
\hline Chlorophyll $a$ & $0.88 \pm 0.23 \mathrm{a}$ & $0.90 \pm 0.08 \mathrm{a}$ & $1.01 \pm 0.17 \mathrm{a}$ & $0.44 \pm 0.11 \mathrm{~b}$ \\
Chlorophyll $b$ & $1.58 \pm 0.33 \mathrm{a}$ & $1.29 \pm 0.24 \mathrm{a}$ & $1.45 \pm 0.26 \mathrm{a}$ & $0.63 \pm 0.17 \mathrm{~b}$ \\
\hline Mambu & $\mathbf{1 3 / 0 2 / 9 8}$ & $\mathbf{0 1 / 0 5 / 9 8}$ & $\mathbf{1 2 / 0 8 / 9 8}$ & $\mathbf{0 4 / 1 1 / 9 8}$ \\
\hline Chlorophyll $a$ & $1.12 \pm 0.77 \mathrm{a}$ & $1.02 \pm 0.19 \mathrm{a}$ & $1.07 \pm 0.33 \mathrm{a}$ & $0.83 \pm 0.13 \mathrm{a}$ \\
Chlorophyll $b$ & $2.07 \pm 0.14 \mathrm{a}$ & $1.67 \pm 0.47 \mathrm{a}$ & $1.63 \pm 0.53 \mathrm{a}$ & $1.42 \pm 0.22 \mathrm{a}$ \\
\hline
\end{tabular}




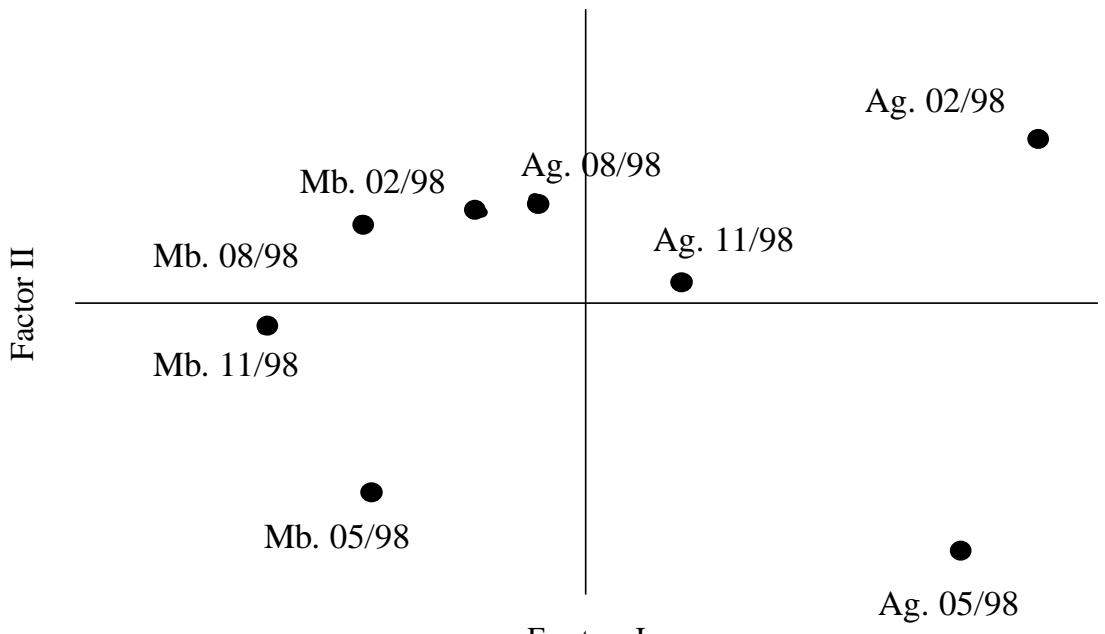

Figure 1 - Principal component ordination (components I and II) of sites and months (February, May, August and November) for the Aguapeú River (Ag) and Mambu River (Mb).

Table 6 - Values (maximum and minimum) of the net photosynthesis $\left(\mathrm{mg} \mathrm{O}_{2} \mathrm{~g}^{-1} \mathrm{PS} \mathrm{h}^{-1}\right)$ of different species of submerged aquatic macrophytes. The values of the water temperature are given in parenthesis. Legend: $\mathrm{S}=$ surface and $\mathrm{B}=$ bottom. (* laboratory experiment in temperate climate).

\begin{tabular}{|c|c|c|c|}
\hline \multirow[t]{2}{*}{ Species } & \multicolumn{2}{|c|}{ Net Photosynthesis $\left(\mathrm{mgO}_{2} / \mathrm{gDW} / \mathrm{h}\right)$} & \multirow[t]{2}{*}{ Author } \\
\hline & Minimum & Maximum & \\
\hline Potamogeton pectinatus & $2.19\left(10^{\circ} \mathrm{C}\right)$ & $19.67\left(20^{\circ} \mathrm{C}\right)$ & $\begin{array}{c}\text { Menendez and Sanchez } \\
(1998) *\end{array}$ \\
\hline Chara hispida & $2.55\left(10^{\circ} \mathrm{C}\right)$ & $10.86\left(20^{\circ} \mathrm{C}\right)$ & $\begin{array}{c}\text { Menendez and Sanchez } \\
\text { (1998)* }\end{array}$ \\
\hline Ruppia cirrhosa & $5.00\left(10^{\circ} \mathrm{C}\right)$ & $10.92\left(23^{\circ} \mathrm{C}\right)$ & $\begin{array}{c}\text { Menendez and Peñuelas } \\
(1993) *\end{array}$ \\
\hline \multirow[t]{2}{*}{ Ranunculus aquatilis } & $1.90\left(5^{\circ} \mathrm{C}\right)$ & $5.92\left(15^{\circ} \mathrm{C}\right)$ & Madsen and Brix \\
\hline & $4.31\left(\mathrm{P}_{\max }\right)$ & $17.23\left(\mathrm{P}_{\max }\right)$ & $(1997) *$ \\
\hline \multirow[t]{2}{*}{ Elodea canadensis } & $1.12\left(5^{\circ} \mathrm{C}\right)$ & $7.37\left(15^{\circ} \mathrm{C}\right)$ & Madsen and Brix \\
\hline & $2.96\left(\mathrm{P}_{\max }\right)$ & $28.72\left(\mathrm{P}_{\max }\right)$ & $(1997) *$ \\
\hline Egeria densa & $5.85\left(20^{\circ} \mathrm{C}, \mathrm{S}\right)$ & $9.23\left(21^{\circ} \mathrm{C}, \mathrm{S}\right)$ & This study \\
\hline (Aguapeú River) & $0.46\left(23^{\circ} \mathrm{C}, \mathrm{B}\right)$ & $4.13\left(21^{\circ} \mathrm{C}, \mathrm{B}\right)$ & \\
\hline Egeria densa & $2.76\left(21^{\circ} \mathrm{C}, \mathrm{S}\right)$ & $5.40\left(19^{\circ} \mathrm{C}, \mathrm{S}\right)$ & This study \\
\hline (Mambu River) & $1.18\left(19^{\circ} \mathrm{C}, \mathrm{B}\right)$ & $3.60\left(19^{\circ} \mathrm{C}, \mathrm{B}\right)$ & \\
\hline
\end{tabular}

\section{DISCUSSION}

During this study, a relatively narrow variation of the temperature $\left(20-23^{\circ} \mathrm{C}\right.$ in the Aguapeú River and $18-21^{\circ} \mathrm{C}$ in the Mambu River) of the water of the two rivers was observed (Tables 1 and 2). At the same time, a small variation in the contents of chlorophyll $a$ and $b$ of $E$. densa from both rivers was also observed implying that there were no periods of growth and senescence (Table 5). It has been reported that in tropical regions, there was no significant seasonal changes in the biomass of emergent and submerged species of macrophytes and that the growth of the aquatic vegetation occurred throughout the year (Payne, 1986; Esteves and Camargo, 1986). Menendez and Sanches (1998) noticed differences between the minimum and maximum NP for Potamogeton 
pectinatus (approximately 10 times) and for Chara hispida (approximately 5 times). They also observed that the values for photosynthetic rates, temperature and chlorophyll $a$ and $b$ were generally higher in spring and summer. In a coastal lake in the Northeast of Spain, Menendez and Peñuelas (1993) measured a NP two times higher for Ruppia cirrhosa in spring than in autumn and winter. These differences have been attributed to the seasonal variations of light and temperature (minimum $7^{\circ} \mathrm{C}$ and maximum $30^{\circ} \mathrm{C}$ ) and to the stage of the plant development, autumn and winter coinciding with the senescence period.

Comparison of the data obtained in this study for NP (maximum and minimum) with data from other investigations, carried out in temperate regions, showed evidence of a small amplitude between maximum and minimum values of NP for E. densa (Table 6). This small annual range of NP was probably due to the climatic conditions with narrow seasonal variation.

There was a small difference in E. densa photosynthetic rates measured on the surface of the water in both rivers among the periods of analysis. However, in May the measurements for GP, NP and R taken from the Mambu River were significantly higher from those obtained in the other months.

The higher values of photosynthetic rates obtained in May were probably related to the higher values of PAR measured in the same month. It could be important to mention that the measurements taken on May 1998 (01 and 02) were the only ones taken on sunny days and the PAR in the study area was mainly correlated to the occurrence of sunny and rainy days. The lowest value for GP was measured at the bottom of the Aguapeú River in February and this coincided with the lowest PAR measured. Other authors like Madsen and Sand-Jensen (1994), working with Elodea canadensis and Callitriche cophocarpa, also observed a positive relationship between photosynthesis and light intensity.

It was observed that there was a difference between the GP values from the surface and the ones from the bottom of the Aguapeú River (the former being nine times higher) while the results obtained from the Mambu River were almost the same. The low values for the bottom of the Aguapeú River were probably related to the low PAR attributed to the high value of $k$ in this river. The high $\mathrm{k}$ value was probably due to the dark colour (black) of the water from this river, because the values obtained for the suspended matter and the depth for the two rivers were similar. The lowest GP values were measured at the bottom of Aguapeú River, but the values for the GP on the surface of this river were in average, approximately two times higher than the ones from the Mambu River.

The higher gross photosynthesis of $E$. densa in the Aguapeú River was also probably related to the highest amounts of total $\mathrm{CO}_{2}$ in the water of this river. The inorganic carbon concentration in the water was an important factor that controlled the growth of the submerged macrophyte. SteemannNielsen (1960) stated that the elodeid angiosperms were rare or absent in lakes with low levels of total $\mathrm{CO}_{2}$. Madsen and Sand-Jensen (1987) observed that the growth of Elodea canadensis was very slow in low total $\mathrm{CO}_{2}$ concentrations, whereas Madsen and Sand-Jensen (1994) measured, under laboratory conditions, increased photosynthesis in $E$. canadensis and C. cophocarpa following an increase in total inorganic carbon. The higher phosphorus concentrations in the water and sediment of the Aguapeú River could also explain the higher GP from the surface of this river.

It was possible to conclude, based on the results presented in this paper, that the parameters which controlled the photosynthetic rate of $E$. densa were the PAR and the total $\mathrm{CO}_{2}$ and phosphorous concentration in the water and sediment. E. densa also grew in less favourable conditions, but with lower values of net photosynthesis. The survival ability of $E$. densa under unfavourable conditions was also demonstrated by Feijoó et al. (1996) and this could explain the undesirable growth of $E$. densa in some aquatic ecosystems when the conditions are sub-optimal.

\section{ACKNOWLEDGEMENTS}

We thank Ana Maria Monteiro for the translation the manuscript into English and Prof. Dr. Orlando Necchi Junior for the constructive comments and Carlos Fernando Sanches for the help in the field work. CNPq, proc. 520592/97-2, supported this work. 


\section{RESUMO}

Egeria densa é uma macrófita aquática submersa que, no Brasil, tem causado prejuízos principalmente na geração de energia elétrica. $\mathrm{O}$ objetivo deste estudo é avaliar a taxa fotossintética de E. densa em dois rios com características limnológicas diferentes (Aguapeú e Mambu), ambos pertencentes à bacia do rio Itanhaém. Esta espécie ocorre abundantemente em ambos os rios, mas sem causar danos aos seus usos múltiplos. As determinações das taxas fotossintéticas foram realizadas em fevereiro, maio, agosto e novembro de 1998 e as variáveis limnológicas da água e do sedimento também foram analisadas. A maior fotossíntese bruta (FB) foi medida em maio $(10,06$ no rio Aguapeú e $6,10 \mathrm{mgO}_{2} / \mathrm{gDW} / \mathrm{h}$ no rio Mambu), quando a radiação fotossinteticamente ativa (RFA) também foi maior (1126,7 e 895,7 $\mu \mathrm{mol} / \mathrm{m}^{2 /} \mathrm{s}$, respectivamente). $\mathrm{FB}$, fósforo total, $\mathrm{CO}_{2}$ total e RFA foram sempre maiores no rio Aguapeú.

\section{REFERENCES}

Allen, S. E.; Grimshaw, H. M.; Parkinson, J. A. and Quarmby, C. (1974), Chemical analysis of ecological materials. Oxford : Blackwell Scientific Publications. $565 \mathrm{pp}$.

Camargo, A. F. M. and Esteves, F. A. (1995), Biomass and Productivity of Aquatics Macrophytes in Brasilian Lacustrine Ecossystems. In: Tundisi, J. G.; Bicudo C. E. M. and Matsumara Tundisi, T (Eds.). Limnology in Brazil. Rio de Janeiro : ABC/SBL. pp 137-149.

Camargo, A. F. M.; Nucci, P. R.; Bini, L. M. and Silva Jr., U. L. (1997), The influence of the geology on the limnological characteristics of some lotic ecosystems of the Itanhaém River Basin, SP-Brazil. Verh. Internat. Limnol., 26, 860-864.

Clesceri, L. S.; Greenberg, A. E. and Trussell, R. R. (1989), Standard Methods. For the examination of water and wastewater. Washington : American Public Health Association. 1484 pp.

Esteves, F. A. (1980), Die Bedeutung der aquatischen Makrophyten für den Stoffhaushalt des Schöhsees. III Die anorganischen Hauptbestandteile der aquatischen Makrophyten. Gewässer u. Abwasser, 66/67, 29-94.

Esteves, F. A. and Camargo, A. F. M. (1986), Sobre o papel de macrófita aquática na estocagem e ciclagem de nutrientes. Acta Limnológica Brasiliensia, 1, 273-298.

Esteves, F. A. (1998), Fundamentos de Limnologia. Rio de Janeiro : Interciências/FINEP. 575 pp.
Feijoó, C. S.; Momo, F. R.; Bonetto, C. A. and Tur, N. M. (1996), Factors influencing biomasss and nutrient content of the submersed macrophyte Egeria densa Planch. in pampasic stream. Hydrobiologia, 341, 21-26.

Golterman, H. L.; Clymo, R. S. and Ohsntad, M. A. M. (1978), Methods for chemical analysis of fresh waters. Boston : Blackwell. 214 pp.

Koroleff, F. (1976), Determinacion of nutrients. In: Grasshoff, K. (Ed). Methods of seawater analysis. New York : Verlag Chemie Weinhein. pp. 117-181.

Lamparelli, C. C. and Moura, D. O. (Coords.) (1998), Mapeamento dos ecossistemas costeiros do Estado de São Paulo. São Paulo : Secretaria do Meio Ambiente, CETESB. 338 pp.

Ludwig, J. A. and Reynolds, J. F. (1988), Statistical Ecology. A primer on Methods and Computing. New York : Jonh Wiley and Sons Inc.

Mackereth, F. J. H.; Heron, J. and Talling, J. F. (1978), Water Analysis: Some revised methods for limnologists. Freshwater Biological Association, Scientific Publication, 36, 121.

Madsen, T. V. and Sand-Jensen, K. (1987), Photosynthetic capacity, bicabonate affinity and growth of Eloidea canadensis exposed to different concentrations inorganic carbon. Oikos, 50, 176-182.

Madsen, T. V. and Sand-Jensen, K. (1994), The interactive effects of light and inorganic carbon on aquatic plant growth. Plant, Cell and Environment, 17, 955-962.

Madsen, T. V. and Brix, H. (1997), Growth, photosynthesis and acclimation by two submerged machophytes in relation to temperature. Oecologia, 110 : (3), 320-327.

Madsen, T. V.; Hahn, P. and Johansen, J. (1998), Effects of inorganic carbon supply on the nitrogen requirement of two submerged macrophytes, Elodea canadensis and Callitriche cophocarpa. Aquatic Botany, 62, 95-106.

Madsen, J. D. (1998), Overview of the Ecological Assessment Technology Area. Aquat. Plant Manage 36, 25-27.

Menendez, M. and Peñuelas, J. (1993), Seasonal photosynthetic and respiratory responses of Ruppia cirrhosa (Petagna) to changes in light and temperature. Arch. Hydrobiol., 129 : (2), 221-230.

Menendez, M. and Sanches, A. (1998), Seasonal variations in P-I responses of Chara hispida L. and Potamogeton pectinatus L. from stream mediterranean ponds. Aquatic Botany, 61, 1-15.

Payne, A. I. (1986), The ecology of tropical lakes and rivers. New York : Jonh Wiley and Sons. 301 pp.

Sand-Jensen, K. (1989), Environmental variables and their effect on photosynthesis of aquatic plant communities. Aquatic Botany, 34, 5-25. 
Seshavatharam, V. (1990), Tradicional uses and problem of noxious growth. In: Gopal, B (Ed.). Ecology and management of aquatic vegetation in the Indian Subcontinent. Kluwer Academic Publishers, Dodrecht. Pp. 201-218.

Spencer, W. and Bowes, G. (1990), Ecophysiology of the world's most troublesome aquatic weeds. In: Pieterse, A. H. and Murphy, K. J. (Eds.). Aquatic weeds. The ecology and management of nuisance aquatic vegetation. New York : Oxford Science Publications. pp. 40-51.

Steemann-Nielsen, E. (1960), Uptake of $\mathrm{CO}_{2}$ by the plant. In - Encyclopedia of Plant Physiology. W. Ruhland (Ed.). Berlin : Springer Verlag. pp. 70-84.

Thomaz, S. M.; Bini, L. M.; Souza, M. C.; Kita, K. K. and Camargo, A. F. M. (1999), Aquatic Macrophytes of Itaipu Reservoir, Brazil: Survey of Species and Ecological Considerations. Brazilian Archives of Biology and Technology, 42 : (1), 15-22.

Wetzel, R. G. (1975), Limnology. USA :W. B. Sauders Company. 743 pp.

Wilkinson, L. (1990), Systat: System for statistic. Evanston, IL. Systat inc.

Vollenweider, R. A. (1974), A manual on methods for Measuring Primary Production in Aquatic Environments. $2^{\text {nd }}$ ed. Oxford : Blackweel Scientific Publications Osney Mead. 225 pp.

Received: November 05, 2001; Revised: August 07, 2002; Accepted: May 14, 2003. 